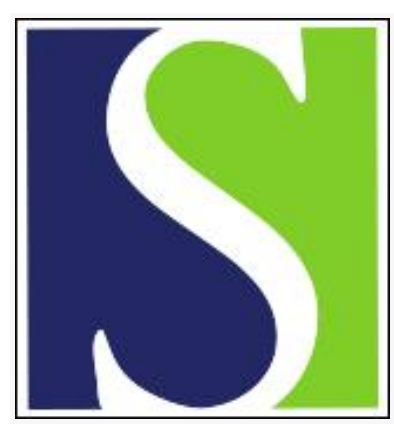

Scand J Work Environ Health 2015;41(4):417-418

https://doi.org/10.5271/sjweh.3503

Published online: 14 May 2015, Issue date: 01 Jul 2015

Re: Fitzgerald et al. "Eligibility for low-dose computerized tomography screening among asbestos-exposed individuals" by Descatha A, Ollivier S, Despreaux T

Affiliation: Unité de pathologie professionnelle/UMS 011 /SAMU92, CHU Poincaré, 104 bd Poincaré, 92380 Garches, France. alexis.descatha@inserm.fr]

Refers to the following text of the Journal: 2015;41(4):407-412

Key terms: asbestos; asbestos exposure; cancer; low-dose computerized tomography; lung cancer

This article in PubMed: www.ncbi.nlm.nih.gov/pubmed/25972090 


\section{Re: Fitzgerald et al. "Eligibility for low-dose computerized tomography screening among asbestos-exposed individuals"}

There is still an ongoing debate about lung cancer screening with low-dose computed tomography (LDCT) (1-4). We read with particular interest Fitzgerald et al's recent paper that detailed eligibility for lung cancer screening using this method (5). Some observations in France about the related question of asbestos might give further useful insight into complicated questions relevant to lung cancer screening and its financial consequences.

In 2010-2011, the French National Authority for Health arbitrated a very broad debate between all interested parties (ie, patients, doctors, scientists, politicians and lobbyists, employers) concerning asbestos in the workplace (6). Chest CT was accepted as the standard imaging procedure (a former recommendation of X-rays was considered useless) to be carried out every 5 or 10 years, depending on the cumulative exposure at work as assessed by an occupational health specialist - and at 20-30 years after the first year of exposure. This decision was based on the currently available medical evidence, but also on financial consequences, taking two aspects into consideration. First, all asbestos disorders diagnosed might be compensated, from cancer to asbestosis, this comprises all pleural disorders related to asbestos exposure, including plaques (based on the subsequent anxiety, and the higher probability of later cancer) (7); and a follow-up by a specialist is offered, taking into account the possibility of complications from "too much medicine" including aspecific pulmonary nodules) $(8,9)$. The second aspect was the asbestos companies' funding of consequences, based on the attributable fraction of risk in exposed individuals and populations.

Thus, we encourage consideration of the possibility of involving all stakeholders who might play a role in the etiology of lung cancer (directly or indirectly, asbestos and also tobacco companies), in order to decide who should assume the charges for all consequences of such screening.

\section{Acknowledgments}

We would like to thank Richard Carter for helping us to improve the language of this work.

\section{Conflict of interest}

Thomas Despreaux and Selene Ollivier have no relevant conflict of interest. Alexis Descatha has received fees from the National Health Insurance for work compensation for his expertise in the field (indemnity independent of any decisions he has made about accepting or refusing cases), and from Elsevier Masson as editor-in-chief of the journal Les Archives des Maladies Professionnelles et de l'Environnement. He is also an administrator for the Fond d'Indemnisation des Victimes de l'Amiante (Asbestos Victims Indemnisation Fund) as an unpaid expert.

\section{References}

1. Woolf SH, Harris RP, Campos-Outcalt D. Low-dose computed tomography screening for lung cancer: how strong is the evidence? JAMA Intern Med. 2014;174(12):2019-22. http:// dx.doi.org/10.1001/jamainternmed.2014.5626.

2. Parker MS, Groves RC, Fowler AA, Shepherd RW, Cassano AD, Cafaro PL, et al. Lung Cancer Screening With Lowdose Computed Tomography: An Analysis of the MEDCAC Decision. J Thorac Imaging. 2015;30(1):15-23. http://dx.doi. org/10.1097/RTI.0000000000000119.

3. Courtright K, Manaker S. Counterpoint: Should lung cancer screening by chest CT scan be a covered benefit? No. Chest. 2015 Feb;147(2):289-92. http://dx.doi.org/10.1378/ chest.14-2815.

4. Tanoue LT, Tanner NT, Gould MK, Silvestri GA. Lung cancer screening. Am J Respir Crit Care Med. 2015;191(1):19-33. http://dx.doi.org/10.1164/rccm.201410-1777CI.

5. Fitzgerald NR, Flanagan WM, Evans WK, Miller AB. Eligibility for low-dose computerized tomography screening among asbestos-exposed individuals. Scand J Work Environ Health. 2015;41(4):407-412. http://dx.doi.org/10.5271/ sjweh.3496.

6. Conso F. Les référentiels en santé au travail : des instructions techniques aux recommandations de bonne pratique. Arch Mal Prof Environ. 2011;72(2):117-8. http://dx.doi.org/10.1016/j. admp.2011.02.001.

7. Pairon J-C, Andujar P, Rinaldo M, Ameille J, Brochard P, Chamming's S, et al. Asbestos exposure, pleural plaques, and the risk of death from lung cancer. Am J Respir Crit Care Med. 2014;190(12):1413-20. http://dx.doi.org/10.1164/ recm.201406-1074OC. 
8. Moynihan R, Heneghan C, Godlee F. Too much medicine: from evidence to action. BMJ. 2013;347:f7141. http://dx.doi. org/10.1136/bmj.f7141.

9. Overdiagnosis: too much of a good thing? Br J Hosp Med (Lond). 2014 Dec;75(12):664-5. http://dx.doi.org/10.12968/ hmed.2014.75.12.664.

Alexis Descatha, MD, PhD, 1, 2, 3,4 Selene Ollivier, MD student, ${ }^{1}$ Thomas Despreaux, MD ${ }^{1}$
1 Paris Hospital (AP-HP) Occupational Health Unit, Poincaré University Hospital, Garches, France.

2 Inserm, Population-based Epidemiologic Cohorts Unit, UMS 011, Villejuif, France.

3 Inserm, VIMA : Aging and chronic diseases. Epidemiological and public health approaches, U1168, F-94807, Villejuif, France

4 Versailles St-Quentin University, UMS 011 UMR-S 1168, Villejuif, France.

Correspondence to: Prof. Alexis Descatha, Unité de pathologie professionnelle/UMS 011 /SAMU92, CHU Poincaré, 104 bd Poincaré, 92380 Garches, France. [E-mail: alexis.descatha@ inserm.fr] 